\title{
INTRODUÇĀO
}

Octavio lanni"*

No começo da história, a terra parece disponivel, dada, dádiva, inocente. É extensa, sem-fim, lonjura, sertão. "De ponta a ponta é toda praia... muito chã e muito formosa. Pelo sertáo nos pareceu, vista do mar, muito grande; porque a estender olhos, não podíamos ver senão terra e arvoredos - terra que nos parecia muito extensa. Até agora não podemos saber se há ouro ou prata nela, ou outra coisa de metal, ou ferro; nem lha vimos. Contudo a terra em si é de muito bons ares frescos e temperados... As águas são muitas; infinitas. Em tal maneira é graciosa que, querendo-a aproveitar, dar-se-á nela tudo". ${ }^{1}$

Parece tão alheia ao homem que ele surge como se fosse um intruso, deslocado, exótico. "A impressão dominante que tive, e talvez correspondente a uma verdade positiva, é esta: o homem, ali, é ainda um intruso impertinente. Chegou sem ser esperado nem querido - quando a natureza ainda estava arrumando o seu mais vasto e luxuoso salão. E encontrou uma opulenta desordem..."2

Entretanto, a terra logo se apresenta como uma vasta dispensa de meios de subsistência, um imenso arsenal de instrumentos de trabalho. No intercâmbio com a terra, o homem extrai os elementos indispensáveis à satisfaçáo de necessidades tais como comer, beber, vestir-se, abrigar-se; $\mathrm{e}$ meios de trabalho. "A terra é sua dispensa primitiva e é, ao mesmo tempo, o seu arsenal de instrumentos de trabalho. Oferece-the, por exemplo a pedra que atira, com a qual fricciona, percute, corta etc. E a própria terra é um instrumento de trabalho, ainda que exija, para o seu cultivo, para poder ser utilizada como instrumento de trabalho, toda outra série de instrumentos e um desenvolvimento relativamente grande da força de trabalho. Tão logo o processo de trabalho se desenvolve um pouco, exige instrumentos de trabalho fabricados". 3

* Versăo ampliada de uma exposição apresentada na 35a. Reunião da Sociedade Brasileira para o Progresso da Ciêncía - SBPC, realizada em Belém, em julho de 1983.

* * Sociólogo, professor do Programa de Pós-Graduação em Ciéncias Soclais, Pontifícia Universidade Católica (PUC), São Paulo.

(1) Pero Vaz de Caminha: Certa a El Rei D. Manuel, Introdução e Organizaçio de texto de Leonardo Arroyo, Săo Paulo, Dominus Editora, 1963, p. 67.

(2) Euclydes da Cunhe: $A$ Margem de Historla, Be, edlcğo, Porto, Llvrarla Lollo \& Irmão Editores, 1946, p. 6.

(3) Karl Marx: El Capital, 3 tomos, Tradução de Wenceslao Roces, México, Fondo de Cultura Económica, 1946-47, Tomo 1, p. 201; citação extraida do cap. V, intitulado "Processo de trabalho e processo de valorizaçăo".

\begin{tabular}{|l|c|c|c|c|c|}
\hline Rev. RAIZES & Campina Grande & Ano II & N. $2-3$ & $5-18$ & jan.-dez./1983 \\
\hline
\end{tabular}


Ao estabelecer intercâmbio com a natureza, em particular a terra, com preendendo àgua, fauna, flora, relevo, recursos minerais, ciclo das estações, fe cundidade etc., o homem apropria-se dela e a transforma. Transforma-se ele tam. bém com ela. Transfigura se.

Desde o começo, a terra é incorporada no processo de trabalho como objeto e meio de produção. Nesse percurso, muda de figura. E retirada da natureza, humanizada. Ao mesmo tempo que é trabalhada e recriada, transforma-se em relação social. Está em marcha a apropriação da terra: tribal, comunitária, clânica, familiar, privada, capitalista. Dá-se a metamorfose da terra em mercado. ria. A produção para o consumo modifica-se em produção para o mercado Realiza-se o estranhamento, a alienação, entre o produtor e a propriedade dos meios de produção. $O$ mesmo processo de apropriação da terra, polarizado entre uso e propriedade, ou posse e domínio, compreende dependências e conflitos entre índios, posseiros, grileiros e muitos outros. Com o desenvolvimento das re: lações capitalistas de produção no campo, a terra se constitui como propriedade privada; para o capital ou do próprio capital. Nesse processo, as diversas metamorfoses da terra compreendem as diversas configurações do trabalho. A humanização da terra, segundo as condiçōes da sociedade burguesa, compreende a sua transformação em relação social, relação de produção, propriedade burguesa. A natureza transfigura-se em história na trama das relações de produçăo, das con. tradições de classes.

\section{REVOLUÇĀO AGRARIA}

As leis de terras, principalmente as que tratam de terras indigenas, devolutas, públicas, de colonização oficial e particular, definem estabelecimentos a imóveis rurais, classificam os trabalhadores do campo, todas assinalam aspectos importantes das pendências e conflitos agrários. Indicam a maneira pela qual o poder estatal tem sido levado a acomodar, ou favorecer e contrariar, interesses das mais diversas categorias sociais envolvidas na luta pela posse e uso da terra indios, ex-escravos, camaradas, imigrantes, moradores, colonos, agregados, assalariados, sitiantes, posseiros, parceiros, meeiros, arrendatários, grileiros, latifundiáríos, fazendeiros, empresários.

A lei de 1850 foi um marco na história da terra. Extingue o prinćpio da doação e inaugura o da compra, para aquisição de terras devolutas. Tratava-se de dificultar o acesso à terra, por parte de ex-escravos, camaradas, imigrantes, colonos, moradores e outros. Ao mesmo tempo que favorecia a monopolizaçäo da propriedade da terra por fazendeiros e latifundiários, induzia os trabalhadores rurais a venderem a sua força de trabalho nas plantações de café, criaçóes de gado e outras atividades. Ao longo dessa história, ocorria a transição do trabalho escravo ao livre, formava-se o mercado da forca de trabalho, expandia-se a monopolização da terra, ocorria a metamorfose da terra em mercadoria.

Outras leis destinaram-se a aperfeiçoar ou desenvolver as condições de 
expansão do capitalismo no campo. A medida que crescia, ou diversificava-se, a economia agrária, em função da exportação, mercado urbano e industrialização, aprimoravam-se os dispositivos jurf́dico-polfticos destinados a regular as relações de produção na agricultura.

LEm 1963 foi criado o Estatuto do Trabalhador Rural, que diz respeito às condições de oferta e demanda da força de trabalho no campo. Institui a carteira profissional, o contrato de trabalho, os direitos e deveres das partes contratantes quanto a salários, descanso remunerado, férias, trabalho do menor, da muther e outros aspectos das relações de produção. Naturalmente define "trabalha dor rural", "empregador rural", "indústria rural" e outras categorias. A rigor, sistematiza as condições jurfdico-polfticas do processo de trabalho, condições essas às quais se submete o assalariado permanente, avulso ou temporário. É óbvio que esse estatuto organiza, delimita o orienta boa parte do intercâmbio entre o homem e a terra, em termos do trabatho compreendido como um processo de pro. dução de mercadoria e mais-valia. Aliás, toda legislação sobre as condições de trabalho, do escravo ao trabalhador livre, do colonato e aviamento ao morador e temporário, compreende uma dimensão essencial da história da terra, das pen. dências e conflitos sobre a posse e o uso da terra. 4

Em 1964 criou-se o Estatuto da Terra, que pode ser tomado como mais um elo importante na história da luta pela terra. Em lugar de expressar apenas, ou principalmente, a resolução de problemas, essa e outras leis anteriores e posteriores expressam a continuidade das pendências e conflitos. História que não termina. 5

A legislação espec lfica sobre as terras indígenas não foge a essa tendência. Desde a Colônia e o Império, as comunidades indígenas foram progressivamente expropriadas. Apesar dos movimentos de opinião pública e da criação do Serviço de Proteção aos Indios (SPI), em 1910, e da Fundação Nacional do Índio (FUNAl), em 1967, essas terras continuaram a ser invadidas, exploradas e expropriadas por grileiros, posseiros, latifundiários, fazendeiros e empresários, freqüentemente mediante a omissão ou cumplicidade dos setores governamentais. Nos tempos do SPI, esta era a situaçăo " Depois de cinqüenta anos de esfor-

(4) Estatuto do Traba/hador Rural, Lel n. 4.214, de 2 de marco de 1963. Consultar tam. bém: Frances Rocha, Conflito Social e Dominaçáo: Um Estudo sobre as Leis de Regula. cáo das Relaçóes de Trabalho na Empresa Agricola (1897.1930), mimeo, PUC, São Pau. 1o, 1982; Octavio lanni, "O Estado e o Trabalhador Rural", Contexto, n. 4, Săo Paulo, 1977, pp. 1.75.

(5) Ruy Cirne Lima: Pequena História Territorial do Brasil (Sesmarias e Terras Devolutas), Porto Alegre, Edição Sulina, 1954; Instituto Nacional de Colonização e Feforma Agrária (INCAA), Vade-Mecum Agrário, 7 vols. Centro Gráfico do Senado Federal, Braślia, 1978. Cabe destacar: Lei n. 601 , de 18 de setembro de 1850 ; Decreto $n .19 .924$, de 27 de abril de 1931; Decreto Lei n. 9.760 , de 5 de setembro de 1946; Lei Delegada n. 11, de 11 de outubro de 1962; Lei n. 4.504, de 30 de novembro de 1964; Decreto-Lei $n$. 1.110, de 9 de julho de 1970; e lei n. 6.383, de 7 de dezembro de 1976 . 
ços para garantir a cada tribo uma nesga de terra, ainda såo poucos os Estados que deram aos indios titulos de posse das terras em que vivem. E a grande maioria deles vazou o texto legal em linguagem tão imprecisa que dá margem a discussões, cada vez que um fazendeiro ou político local se decide a lançar mão de suas relações políticas para apossar-se de terras dos indios. Duas expectativas muito claras estão implicitas nestes documentos: a de que a população indígena tende a diminuir até o completo desaparecimento a de que os indios acabarão por integrar-se na população sertaneja, na condição de lavradores sem terras... A pacificação de uma tribo tem representado sempre a redução de seu território de caça e coleta, invadido por extratores de produtos da mata, agricultores ou criadores de gado, conforme a economia dominante na região"6 Nem a FUNAI encaminhou soluções satisfatórias. $O$ que sobra das terras indigenas são terras ameaçadas. "A situação das terras ind/genas pode ser definida, de modo geral, como situação que envolve três características: terras ameaçadas de invasăo pelos brancos, sobretudo grandes fazendas e empresas; terras griladas, cuja posse pelo não-fndio ainda depende de regularização; e terras expropriadas, cuja posse e domínio já estão legalmente nas mãos de brancos... A medida em que se deteriora a forma de ocupação e utilização da terra pelo indio, como conseqüência da sua invasão e inçorporação por fazendas e empresas, também se deteriora a sua identidade tribal. A destruiçẩo do espaço do indio destrói também as condições de reprodução do seu modo de ser... Mesmo as terras devolutas e as terras indígenas já estão no cálculo do capital"'.7

A luta pela terra, no Brasil, vem de longe. E agrava-se em certas épocas. Há freqüentes surtos mais ou menos intensos de pendências e conflitos. Provavelmente têm relação com os surtos de expansão do capital no campo. A entrada do país na industrialização acelerada, com acentuada participação do poder estatal, parece ter inaugurado outra onda de pendências e conflitos. Na década dos cinqüenta, por exemplo, surgiu o movimento dos posseiros de Trombas e Formoso, em Goiás; movimento de grande significą̧̃o social e política. Em termos diversos, mas também com significativas implicaçōes sociais e polticicas, surgiram os conflitos do oeste paranaense. A construçäo da rodovia Belém-Brasılia abriu outros focos de atritos. Depois, continuaram a repetirse em diferentes regionss do país. Desde que entrow em nova fase o desenvolvimento extensivo e intensivo do capitalismo no campo, em especial a partir da instalaçåo da ditadura militar de 1964, reativaram-se antigas lutas e multiplicaram-se novas. As comunidades indígenas, os núcleos de posseiros, os bairros caboclos, as colônias, além de parceiros, meeiros, arrendatários, moradores outros trabalhadores rurais, muitos passaram a enfrentar problemas quanto ao uso e posse das terras nas quais vivem

(6) Darcy Ribeiro: A Polltica Indigenista Brasileira, Rio de Janeiro, Serviço de Informação Agrícola, 1962, pp. 106-107.

(7) José de Souza Martins: Expropriaça e Violência (A Questao Polftica no Campol, São Paulo, Editora Hucitec, 1980, pp. 153-155. 
e trabalham.

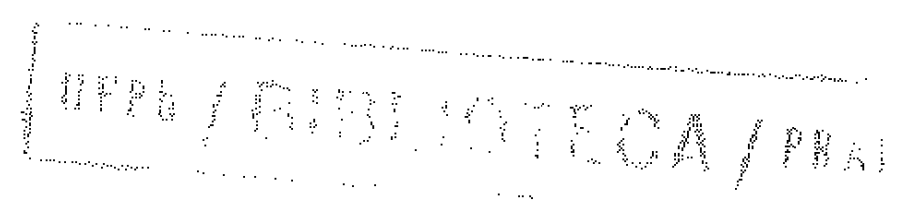

No Rio Grande do Sul, o colono descendente de imigrantes italianos, na área do vinho, diz que é uma grande coisa ter um pedaço de terra. Assim não se depende muito dos outros. "Porque quando eu tenho a terra eu faço por mim mesmo. Não tendo a terra, tem de andar debaixo do dono. Quer dizer, assim eu sou o dono. $E$ assim estou vivendo na terra. Se não tivesse a terra não posso sustentar a famnia"8. Em muitas partes do pals, repete-se a reivindicação. Em São Paulo, segundo um bóia-fria: "A situação melhorava se o governo desse um pedaço de terra para nós". Mas a ajuda não vem. O governo "não dá terra nem emprego" 9 . Para o arrendatário, o problema é garantir a permanência na terra. "Porque nós queríamos era trabalhar, nós quer famos plantar para dar aos filhos para comer"10. Em Minas Gerais o posseiro relata como chegou a violên. cia. "Tinha feito pasto e plantava muita roça. Então chegou o pessoal da Ruralminas. Invadiram a terra, puseram gado nas plantações. Foi uma tristeza. Muitos se apavoraram, venderam o que tinham e foram embora" 11 . Em Golás, outro posseiro fala da resistência em defesa da terra. "A reivindicação era só, única de todos. Nós não tínhamos latifúndio... olho grande. Eram todos os posseiros. A luta era contra o grileiro, contra o Estado, para legalizar a terra" 12 . E o migrante fala do campo e da cidade. "A roça é mãe, você planta um pé de maxixe, uma semente de melancia, tudo já serve para os filhos. E na cidade se eu tiver dinheiro eu como, se não tiver, só faço olhar" ${ }^{13}$. Em Pernambuco continua a relação fundamental com a terra, como objeto e meio de trabalho. Um pequeno produtor sabe que "o problema da gente é terra, porque o sujeito tendo terra de tudo planta, planta milho, planta feijão, planta mandioca, planta inhame, planta essa coisa todinha... Toda riqueza sai da terra... A terra pode-se dizer que é o maior tesouro do mundo" 14. Como diz o galileu, "o que um fraco pode fazer sem um sitio? Só pode morrer, que é dall que ele tem seu pão de cada dia e o viver de sua famfia. Mesmo que o mundo se acabe, se ele tem sua terrinha tem onde vi-

(8) José Vicente Tavares dos Santos: Colonos do Vinho, Säo Paulo, Editora Hucitec, 1978, pp. 136-137.

(9) Maria Conceiçáo d'Incao e Mello: O B6ia-Fria, Petrópolis, Editora Vozes, 1975, p. 138.

(10) Vera Lucia Michalany Chaia: Os Conflitos de Arrendatários em Santa Fé do Sul - S.P. (1959-1969), mimeo, São Paulo, Universidade de S5o Paulo, 1980, p. 123.

(11) Wanda Caldeira Brant Monteiro de Castro: Jalba: Expropriacão e Colonizacão, mimeo, São Paulo, Universidade de São Paulo, 1982, cap. 1, p. 19.

(12) Maria Tereza Canesin Guimarães: Formas de Organização Camponesa em Goids (19541964), mimeo, São Paulo, Pontifícia Universidade Católica, 1982, p. 50.

(13) Cláudia Menezes: A Mudança (Análise da Ideologia de um Grupo de Migrantes), Rio de Janeiro, Imago Editora, 1976, p. 72.

(14) Beatriz Maria Alásia de Heredia: A Morada da Vida (Trabalho Familiar de Pequenos Produtores do Nordeste do Brasill, Rio de Janeiro, Editora Paz e Terra, 1979, pp. 144 e 150 . 
ver e como viver" 15. No Estado do Amazonas, um pequeno produtor identifica as terras situadas às margens das estradas como methores, valorizadas. Mas "essas são terras de barão. Quando abriram essa estrada, disseram que ia ter terra para os pequenos; que ia haver um loteamento para os agricultores que quisessem ocupar um lote de terra e tal. Quando abriram as inscriçōes já estava tudo tomado, a só por gente da cidade" 16 . No Pará, a terra parece estar sempre em movimento, como o movimento do posseiro que chega e parte; ele mesmo ou outro. "A terra não demove de nenhum lugar. É o povo que corre para todo lado. Pobre anda caçando destino, andando sempre caçando melhora. $O$ velho meu pai parou no meio da viagem e eu continuei. A jornada do pobre é mudan. ça. O pobre não tem sossego. Sempre a gente é tocado pela situação, procura lugar mais novo. Os mais fracos vão indo na frente, depois chegam os melhor um poquinho de siruaçăo comprando da gente, depois chega a classe média comprando a a gente vai mais para frente de novo. Quando chega o rico mesmo, toca mais para frente. E essa jornada da gente só termina quando a gente morre. Você fica no meio da viagem, os filhos seguem a jornada" 17.

Ao longo dos anos, multiplicaram-se as pendências, brigas, tocaias, emboscadas, enfrentamentos, combates armados de maiores proporçôes. Simultaneamente, surgiram movimentos sociais: uns de base religiosa; outros mais propriamente políticos, como os dos posseiros de Trombas e Formoso, os galileus de Pernambuco, os arrendatários de Santa Fé do Sul. Também surgiram sindicatos e partidos, buscando organizar e orientar os trabalhadores em suas pendências e conflitos. Incłusive as mais diversas agências governamentais passaram a fazer parte das controvérsias: policiais, militares, executivo, judiciário, bancos, superintendências, planos, programas, projetos. Assim, sindicatos, partidos, igrejas e agências do poder estatal mesclam-şe com os movimentos sociais rurais, em suas pendências e conflitos sobre a terra.

Está em marcha uma espécie de revolução agrária, provocada pelo crescimento extensivo e intensivo do capizalismo no campo, espraiando-se da cidade. Desenvolvem-se as forcas produtivas, isto é, o capiral, a tecnologia, a proletarizaçå, a divisão do trabaho, o planejamento governamental; a as relaçoses de produça, compreendendo principalmente a monopolizaçe da tera, em termos de propriedada a exploraçẫo. Esse é o quadro no qual a luta pela terra recoloca o problema clássico da relação entre o homem e a terra, sociedade e natureza. "A bondade das condiçőes naturais não faz senão oferecer a possibilidade, nunca a

(15) Elide Rugai Bastos: Ligas Camponesas (Estudo sobre a Luta dos Camponeses em Pernambucol, mimeo, São Paulo, Universidade de São Paulo, 1980, p. 56.

(16) Ernesto Renan Melo de Freitas Pinto: Os Traba/hadores da Juta (Estudo sobre a Constituição da Produção Mercantil Simples no Médio Amazonas), mimeo, Porto Alegre, Universidade Federal do Rio Grande do Sul, 1982, pp. 81-82.

(17) Maria Antonieta da Costa Vieira: Capando o Destino (Um Estudo sobre a Luta de Resistência dos Posseiros do Sul do Pará), São Paulo, Pontif́cicia Universidado Católica, 1981, p. 26. 
realidade, do trabalho excedente e, portanto, da mais-valia ou do sobre-produto... Com as forças produtivas do trabalho oferecidas pela natureza ocorre o mesmo que com as forças produtivas historicamente desenvolvidas, sociais: são consideradas como forças produtivas do capital, às quais se incorporam" 18. A medida em que caminha a acumulação originária, em suas implicações estruturais, a mercantilização da terra,a produção para o mercado em lugar da produçâo para o auto-consumo, nesse percurso a terra se constitui como objeto e meio de produção de capital.Transforma-se em força produtiva do capital." A agricultura transformase mais e mais em simples ramo da indústria e é dominada completamente pelo capital. A mesma coisa ocorre com a renda da terra. Em todas as formas em que domina a propriedade fundiária, a relação com a natureza é ainda preponderante. Naquelas em que domina o capital, o que prevalece é o elemento produzido social e historicamente. Não se compreende a renda da terra sem o capital, entretanto compreende-se o capital sem a renda da terra. $O$ capital é a potência econômica da sociedade burguesa, que domina tudo. Deve constituir o ponto inicial e o ponto final e ser desenvolvido antes da propriedade da terra. Depois de considerar particularmente um e outro, deve-se estudar sua relação recíproca" 19.

As classes sociais no campo aparecem como condição e produto da revoluçáo agrária. Desenvolvem-se, em termos quantitativos e qualitativos, o proletariado, o campesinato, a pequena burguesia e a grande burguesia; além de uma tecnocracia mais ou menos importante, composta de engenheiros agrónomos, veterinários, administradores, economistas, gerentes e outros profissionais. $\mathrm{Si}$ multaneamente, intensificam-se e diversificam os laços entre a cidade e o campo, a indústria e a agricultura, as classes sociais urbanas e rurais, os movimentos sociais e os sindicatos e partidos políticos. Está em marcha a transformação do trabalhador rural em cidadão, da mesma maneira que a generalização das classes sociais e os seus antagonismos.

\section{FORMAS DA TERRA}

A terra que está em causa não é uma só, homogênea. Ao contrário, é diversa, múltipla. São diferentes as formas sociais da terra, da organização das atividades produtivas, reveladas pelas pendências e conflitos. Há núcleos indígenas, caboclos, sitiantes, posseiros e outros que podem estar voltados principal-

(18) Karl Marx: El Capital, 3 tomos, Tradução de Wenceslao Roces, México, Fondo de Cultura Económica, 1946-47, Tomo I, pp. 566-567.

(19) Karl Marx: Elementos Fundamentales para la Critica de la Economía Política (Borrador) 1857-1858, 3 vols., Mexxico, traduçấo de José Aricó, Miguel Murmis e Pedro Scarón, Siglo Veintiuno Editores, 1971, vol. 1, P. 28. Aproveito a traduça feita por José Arthur Giannotti e Edgar Malagodi: Karl Marx, "Introduçáo à Cr/tica da Economia Polftica", publicada no volume Marx, da coleçäo "Os Pensadores", São Paulo, Abril S. A. Cultural e Industrial, 1974, pp. 127-128. 
mente para o auto-consumo, a subsistência dos seus membros. Outros ainda combinam a produção para o comércio e subsistência. Assim como há aqueles que se dedicam totalmente à produção de mercadorias. E sẫo muitos os casos de produção bastante tecnificada, com base em máquinas e equipamentos, fertilizantes e defensivos. Todas essas e outras modalidades situam-se no âmbito de um sistema económico baseado em fazendas, cooperativas, latifúndios, empresas, agro-indústrias. Marcando as tendéncias principais do todo, compreendendo o campo e a cidade, está o grande capital industrial e financeiro, com fortes articulações nos movimentos internacionais do capital. "Em todas as formas de sociedade se encontra uma produção determinada, superior a todas as demais, e cuja situação aponta sua posição e influência sobre as outras. E uma luz universal de que se embebem todas as cores, e que as modifica em sua particularidade. E um éter especial, que determina o peso especiffico de todas as coisas emprestando relevo a seu modo de ser" 20.

Essa lluminação e influencia ocorre com as terras tribais, devolutas, ocupadas, griladas e tituladas; que compreendem comunidades, sítios, cooperativas, fazendas, latifúndios, empresas; terras boas e fracas; próximas e distantes de rios, rodovias, ferrovias, mercados, concentrações urbano-industriais. Situam-se nas travessias das marchas para oeste, frentes de expansão, pioneiras fronteiras. Há surtos do capital que se espraiam longe, em terras-do-sem-fim, lonjuras. Agora, a fronteira está acabando na Amazônia, mas já andou pelo oeste paulista, oeste paranaense, sul de Mato Grosso, na travessia da Belém-Brasilia ao longo de Goiás. Cada forma social da terra compreende um modo de intercámbio do homem com a terra, da sociedade com a natureza. Säo múltiplas as possibilidades de organização social da produção, ainda que amplamente articuladas pelo mercado, iluminadas pelos movimentos do capital. Mesmo assim, no entanto, persistem, ou mesmo aumentam as diversidades. Sob tałs condições, a terra não é mais uma só, homogênea, mesma.

A colonização também altera, ou define mais nitidamente, certas formas sociais da terra. A história da colonização mostra que ela pode ser espontânea ou dirigida, particular ou governamental. Combina pequenas unidades camponesas, cooperativas, empresas agricolas ou empreendimentos agro-industriais complexos. Em suas diversas modalidades, portanto, a colonização implica em diferentes maneiras de organizaçäo do trabaho e da propriedade. Em geral, a colonização dirigida estabelece fortes laços entre os trabałhadores agrícolas - colonos, cooperados e assalariados permanentes e temporários - com a produção de mercadorias; o que implica o mercado, o sistema bancário e as agéncias

(20) Karl Marx: Elementos Fundamentales para la Critica e la Economia Pol/tica (Borrador) 1857-1858, 3 vols., México, trad. de José Aricó, Miguel Murmis e Pedro Sacarón, Siglo Veintiuno Editores, 1871, vol. 1, p. 27.28. Aproveito a tradução felta por José Arthur Giannotti e Edgar Malagodi : Karl Marx: "Introdução à Cr(tica da Economia Polftica", publicada no volume Marx, da coleção "Os Pensadores", Săo Paulo, Abril S.A. Cultural e Industrial, 1974, p. 127. 
governamentais. Para os interesses predominantes no Estado brasileiro, no qual a agricultura se acha amplamente subordinada ao grande capital industrial e financeiro, a colonizaçăo compreende uma parte importante da reforma agrária possivel, conveniente ou tolerável pelo bloco do poder.

Em geral, a luta pela terra compreende diferentes modalidades de movimentos sociais. As pendências, brigas, emboscadas, tocaias, enfrentamentos, conflitos armados de maiores proporções, baseiam-se, na maioria dos casos, em alguma reaçäo grupal ou coletiva mais ampla. Mobilizam forças, experiências, valores, ideais, reivindicações de alguns ou muitos. No mesmo sentido podemos falar dos movimentos de base religiosa, que também mobilizam as experiências sociais e o patrimônio cultural de alguns ou muitos. É verdade que a maioria dos movimentos sociais, religiosos e polfticos, compreende o intercâmbio entre $\mathrm{a}$ cidade e o campo, entre as reivindicações locais e regionais com as nacionais. $E$ isso freqüentemente modifica o seu caráter, força ou condições de desenvolvimento. As igrejas e os partidos às vezes entram na organização e luta segundo as condições próprias do movimento social que se acha em questão; outras vezes trazem novos elementos, dados, experiencias, alargando e definindo melhor a direção da luta; mas também podem divorciar bases e direção, superpondo-se ou impondo-se ao movimento. Além disso, as forças adversas aos camponeses, operários, Indios, posseiros e outros que formam o movimento, passam a fazer parte das pendências e conflitos. Isso ocorreu, por exemplo, com as ligas camponesas, os galileus de Pernambuco e outros camponeses, desbaratados pela ditadura militar em 1964. "As classes dominantes vão reaglutinar-se, e a resposta aos movimentos sociais agrários vai ser dada via Estado capitalista, através de uma politica coerente com as necessidades do capital - consubstanciada pelo Estatuto da Terra e pelo Estatuto do Trabalhador Rural - e através da repressão aos movimentos sociais no campo" 21. Tanto no Nordeste como em outras regiōes do pals, os governantes mudaram alguma coisa para nada modificar. Assim caminhou a "reforma agrária" conveniente e tolerável pelo bloco do poder. "As reivindicaçōes a mobilização camponesa, a burguesia respondia com propostas de alterações marginais na estrutura fundiária, apoio à colonização, maior severidade na tributaçăo, através de reformulação no Imposto Territorial Rural, intervenção nas áreas de tensão com distribuição de terras públicas, regulamentação de relações tensas como a parceria e o arrendamento, estímulos à formação de uma classe média rural etc., mas sempre enfatizando o respeito às formas vigentes de propriedade" 22. Passando por fases duríssimas de repressão, os movimentos

(21) Elide Rugai Bastos: Ligas Camponesas (Estudo sobre a Luta dos Camponeses em Pernambucol, mimeo, São Paulo, Universidade de São Paulo, 1980, p. 166. Quanto às ligas camponesas, consultar tambem: Francisco Julião: Que São as Ligas Camponesas?, Rio de Janeiro, Editora Civilização Brasileira, 1962; Fernando Antonio Azevedo: As Ligas Camponesas, Rio de Janeiro, Editora Paz e Terra, 1982.

(22) Leonilde Servolo de Medeiros: A Questão da Reforma Agraria no Brasil: 1955-1964, mimeo, São Paulo, Universidade de São Paulo, 1982, p. 137. 
camponeses continuam ou ressurgem. "As lutas camponesas destes últimos anos forçaram o governo a fazer uso treqüente do dispositivo do Estatuto da Terra que prevê a desapropriação por interesse social em caso de tensões sociais, pois as tensões tornaram se diárias" 23 . Na Amazônia, Nordeste, Sul e outras regiões do pals continuam as pendências e os conflitos. No sul do Pará, posseiros e proprietários envolvem-se em "constantes escaramuças, com mortes de ambos os lados. Pela primeira vez, pistoleiros também eram mortos por posseiros, antes vitimas constantes" 24 . No Estado do Rio de Janeiro, ocorre "uma intensa mobilização de trabalhadores rurais", que lutam "pela libertação das terras paradas e presas nas mãos dos grandes proprietários" 25. Também no Rio Grande do Sul continua a luta. "Pode-se reconhecer nos movimentos camponeses recentes no Sul a expressão de uma resistência do campesinato ao processo capitalista de exploração de seu produto, bem como de uma luta acirrada pela preservação e conquista da terra... O campesinato do Sul retoma a luta pela terra e contra a concentração da propriedade fundiária, confronta-se com a politica agrícola e com a dominação das agroindústrias" 26.

$\mathrm{Na}$ prática, as pendências e conflitos relativos à terra caracterizam a marcha da reforma agrária que se realiza no Brasil. Uma reforma agrária de fato, segundo o jogo dos antagonismos e lutas de classes no campo e cidade; conforme os interesses de um bloco de poder no qual sobressai a grande burguesia industrial e financeira.

Fazendo uma síntese, taivez seja possivel afirmar que a controvérsia sobre a reforma agrária levanta principalmente duas tendências: os que reivindicam a divisão da terra, atribuindo as parcelas a trabalhadores rurais como posseiros, parceiros, meeiros, arrendatários, moradores, assalariados e outros; e os que reivindicam a extensão das leis trabalhistas ao campo. Freqüentemente as duas mesclam-se. Essa polarização vem de longos debates. "A luta pela reforma agrária opunha-se a pretensão de simplesmente estender às relaçōes agrícolas os direitos trabalhistas urbanos" 27 . Tratava-se de generalizar os dispositivos jur 1 dicos mais efetivos na cidade, nas relações de produção prevalescentes na indústria. "Certas medidas como a elevação do imposto territorial, a sindicalização dos trabalhadores rurais, a regularização expressa dos contratos de arrendamento e parceria, o respeito aos direitos de cooperativas, a extinção das policias privadas

(23) José de Souza Martins: Os Camponeses e a Polltica no Brasil, Petrópolis, Editora Vozes, 1982, p. 99.

(24) Lúcio Flávio Pinto, "Conflitos de Terras no Sul do Pará", Reforma Agrára, vol. 12, ก. 2, Campinas, 1982, pp. 3-12; cit. p. 12.

(25) Eliane Cantarino O'Dwyer: "Expropriação e Luta dos Camponeses Fluminenses", Reforma Agrario, citada, pp. 13-25; cit. pp. 13 e 25.

(26) José Vicente Tavares dos Santos: "Movimentos Camponeses no Sul: Produto e Terra (1978-1981)", Reforma Agrária, vol. 12, n. 3, Campinas, 1982, pp. 30.54 ; cit. p. 54.

(27) José Cesar Gnaccarini: Latifúndio e Proletariado (Formação da Empresa e Relações de Trabalho no Brasil Rural), São Paulo, Editora Polis, 1980, p. 177. 
etc., são reconhecidas como exigiveis e necessárias, teoricamente, por quase todos" 28 . Entretanto, seria indispensável levar em conta as condições loçais e regionais, a fim de que trabalhadores rurais não acabassem prejudicados. Há formas sociais de organização do trabalho, da relação do homem com a terra, que se acham largamente sedimentadas. "Na economia da caatinga, a divisão da terra seria o tiro de misericórdia na economia, inclusive com a possível liquidação da pecuária. Reforma agrária, para o homem da rua, significa divisão da terra, eliminação do proprietário do latîúndio, eliminação da renda da terra. Se fizéssemos isso na caatinga, nós a despovoar lamos, desorganizando completamente a economia da região, o que seria grave erro. Dadas as condições ecológicas da caatinga e dado o tipo de técnica que ali se utiliza, a subdivisão das terras viria despovoá-la porque nenhum homem pode subsistir na caatinga com uma propriedade pequena, mesmo média. Uma propriedade de 25 hectares, na região, somente provida de uma tomada de água pode subsistir. A unidade de produção na caatinga, para subsistir, precisa ser relativamente grande, pois as terras são pobres e, de certo modo, têm de compensar em quantidade sua deficiência qualitativa" 29 . No mesmo Nordeste, assim como em outras partes do país, ao lado do debate sobre a divisão da terra, havia aqueles que se empenhavam em levar as leis trabalhistas ao campo; ou criar leis que atendessem às diversas formas de organização do trabalho na agricultura. Tratava-se de "retirar da polícia a função tradicional de instrumento de garantia dos privilégios seculares de uma minoria, criando, simultaneamente, condições para o livre exercício, por parte de todos, das franquias democráticas asseguradas pela Constituição" de 1946. O que estava em questão era "a defesa intransigente dos direitos dos trabalhadores das cidades e dos campos", levando em conta a "pressão de baixo para cima, gerada pela ampla camada de trabalhadores rurais que não mais suportava as condições em que viviam" 30 .

Na prática, entretanto, os movimentos relativos à reforma agrária em geral puseram em causa o pacto industrial-agrário que dominou o Estado brasileiro desde 1930 a 1964; e o pacto mais estritamente industrial dominante desde 1964. "O debate entre os setores que defendiam a reforma agrária como instrumento urgente para ampliar o mercado interno e, assim, acelerar o desenvolvimento industrial e os que viam a reforma agrária como uma questão de preparo adequado do trabalhador, era entremeado por argumentos que revelavam a questão política fundamental informadora do discurso: tratava-se do crescimento da organização do movimento camponês, que gerava a necessidade de que se tomas-

(28) Manoel Correia de Andrade: A Terra e o Homem no Nordeste, São Paulo, Editora Brasiliense, 1963, pp. 249-250.

(29) Celso Furtado; $A$ Operação Nordeste: Fio de Janeiro, Instituto Superior de Estudos Brasileiros, 1959, p. 57.

(30) Miguel Arraes: Palavra de Arraes, Rio de Janeiro, Editora Civilizaçáo Brasileira, 1965, pp. 101-104. Quanto às discussões sobre a reforma agrária, consultar também: José Gomes da Silva: A Reforma Agrária no Brasil, Rio de Janeiro, Zahar Editores, 1971. 
sem medidas urgentes para conter o seu potencial" 31. Tanto a partir das suas ralzes propriamente agrárias como em suas expressões mais urbanas, no âmbito dos movimentos sociais rurais e dos partidos polfticos basicamente urbanos, o debate sobre a reforma agrária colocava questões tais como as seguintes : conquista dos direitos de cidadania pelo trabalhador rural; desenvolvimento das classes sociais no campo; questionamento dos interesses agrários prevalescentes no bloco de poder. "As reivindicações camponesas, expressas através de lutas intensas e disseminadas em todo o território nacional, referiam-se quer à posse da terra, quer aos direitos estabelecidos pelas próprias regras consuetudinárias, apontando para a criação, no processo de lutas, de novos direitos. Confrontavam-se, assim, por um lado, com o capital que expulsava posseiros, arrendatários, colonos e moradores e, por esse caminho, rompiam os padrões estabelecidos de relações entre as classes; por outro questionavam a chamada "pax agrária", fundamento do poder econômico e político dos proprietários fundiários" 32 .

A terra é múltipla. Mesmo quando se acha sob forte influência do capital, continua diversa, heterogênea. Expressa distintas maneiras de intercâmbio dos homens entre si, da sociedade com a natureza. As formas pelas quais os homens trabalham a terra conferem distintas formas à terra.

Em perspectiva histórica e teórica ampla, pode-se dizer que no Brasil a luta pela terra expressa a influência de três formas de organização do capital. Naturalmente não se excluem; ao contrário, parecem combinar-se, ainda que em diferentes composições, em termos de desenvolvimento desigual e combinado.

A acumulação originária compreendida principalmente como um processo estrutural (e não apenas em termos da gênese do capital) tem sido responsável pela extensa e intensa monopolização de terras devolutas, tribais ocupadas e outras. Isso implica na transformação, ou rearranjo, das relações entre índios, sitiantes, caboclos, posseiros e outros trabathadores rurais com a terra, enquanto objeto e meio de produção. Generaliza-se o divórcio entre os produtores e a propriedade dos meios de produção. E intensifica-se a violéncia privada e públi$\mathrm{ca}$, de modo a favorecer a monopolização da terra, a proletarização de trabalhadores rurais, inclusive índios.

A fazenda compreende uma forma de organização da propriedade da terra. Inexplorada, semi-explorada ou amplamente aproveitada em cultivo ou pecuária, a fazenda expressa uma relação especifica do homem com a terra. O latifúndio, enquanto grande extensão, pouco ou nada explorado, coloca-se de per-

(31) Leonilde Servolo de Medeiros: A Questão da Reforma Agrária no Brasil, op. cit. pp. 119-120.

(32) Leonilde Servolo de Medeiros: op. cit. pp. 129-130. Consultar também: Abdias Vilar de Carvatho, "Reforma Agrária: Uniáo e Cisão no Bloco Agrário-Industrial", em: Maria N. B. Wanderley, Vilma Figueiredo, Luzia A. C. G. Pinto e Abdias V. Carvalho: Reflexós sobre a Agricultura Brasileira, Rio de Janeiro, Editora Paz e Terra, 1979, cap. 4; Berna. dete W. Aued: $A$ Vitoria dos Vencidos, mimeo, Campina Grande, Universidade Federal da Paralba, 1981. 
meio à fazenda de café, cacau, cana, gado e outras produções; acha se nesse mesmo universo de forças produtivas e relações de produção, como um dos seus polos. De permeio há sítios, posses , moradores, colonos, agregados, índios, caboclos. Nesse contexto também bastante diversificado, mesclam-se grupos e classes sociais: fazendeiros, latifundiários, coronéis, mandões, moradores, colonos, arrendatários, parceiros, meeiros, agregados, camaradas. Aqui combinam-se a subordinação formal e a real do trabalho ao capital.

A empresa agro-industrial é outra forma de organização da relação do homem com a terra. Agora é bastante acentuada a tecnificação do trabalho e da organização do processo produtivo: máquinas e implementos, fertilizantes e defensivos, agrônomos e veterinários, químicos e administradores, sociólogos e assistentes sociais. Neste caso, predomina a subordinação real do trabalho ao capital, o que compreende o desenvolvimento das classes sociais no campo. A burguesia, o operário rural, ao lado de um campesinato bem diversificado, constituem categorias sociais importantes no campo, na relação do campo com a cidade.

Essas três formas marcantes de desenvolvimento do capital, de intercâmbio do homem com a terra, compreendem uma larga variação de formas de organização sociał da produção. Compreendem o desenvolvimento desigual e combinado de formas de trabalho e produção. Combinam-se comunidades ind:genas e fazendas, posseiros e latifundiários, sítios e empresas agro-industriais.

\section{HUMANIZAÇÃo DA TERRA PELO TRABALHO}

E no processo de trabalho que o homem entra em intercâmbio com a terra, apropriando-se dela. A terra transforma-se em uma vasta dispensa de meios de vida e imenso arsenal de instrumentos de trabalho na medida em que é inserida no processo de producăo. Entretanto,à medida em que se desenvolve o intercâmbio entre o homem e a terra, ocorrem distintas metamorfoses da terra. Isto $\dot{e}$, as formas de trabalho, enquanto formas de produção e reprodução, criação $e$ recriaçăo, constituem a terra sob diferentes fisionomias. O intercâmbio do homem com a natureza revoluciona a natureza, ao mesmo tempo em que modifica o homem. Modificam-se as condições de criação e recriação da vida, da terra e do homem.

O que está em causa é a revolução que a indústria provoca na agricultura. Modifica-se o metabolismo entre o homem e a terra, na medida em que as formas de produção agrária são subordinadas ao capital, em modo extensivo e intensivo. Cada vez mais largamente, o tempo do capital, a duração do ciclo de reprodução do capital industrial, invade o ciclo sazonal, o tempo das estações. $A$ natureza se determina, em escala maior, pelos movimentos do capital. "É na órbita da agricultura que a grande indústria tem uma eficácia mais revolucionária", ao destruir, subordinar ou recriar diferentes formas de organização da vida e trabalho. Paulatinamente, ou de maneira abrupta, "as necessidades de transforma- 
çẩo e os antagonismos do campo nivelam+se aos da cidade". A exploração do campo baseia-se cada vez mais na "aplicação tecnológica e consciente da ciência". Sob o regime do capital, criam-se "as condiçōes materiais para uma nova e mais alta síntese, oucoordenaçäo, da agricultura e indústria, sobre a base de suas formas desenvolvidas, em um sentido antagônico. Ao crescer de maneira incessante o predomínio da população urbana, concentrada em grandes centros, a produção capitalista acumula, de um lado, a força histórica motriz da sociedade, enquanto que, de outro lado, perturba o metabolismo entre o homem e a terra; isto é, o retorno à terra dos elementos desta consumidos pelo homem em forma de alimento e vestuário, que constitui a condição natural eterna sobre a qual repousa a fecundidade permanente do solo. Ao mesmo tempo, destrói a saúde ffsica dos operários. Simultaneamente, ao destruir as bases primitivas e naturais daquele metabolismo, obriga a restaurá-lo sistematicamente, como lei reguladora da produção social e sob uma forma adequada ao pleno desenvolvimento do homem... Além do mais, todos os progressos realizados pela agricultura capita. lista não são apenas progressos na arte de exaurir o operário, mas também na arte de exaurir a terra. E, cada passo que se' dá na intensificação da sua fecundidade, dentro de um perfodo de tempo determinado, é, por sua vez, um passo que se dá no esgotamento das fontes perenes que alimentam essa fecundidade... Portanto, a produção capitalista só sabe desenvolver a técnica e a combinação do processo social de produção minando, ao mesmo tempo, as duas fontes originais de toda riqueza: a terra e o homem'33

Essas são as condições sob as quais a terra é retirada da natureza, humanizada. Sob as condições capitalistas de produção, o capital tende a exaurir e refazer periodicamente a terra. Ao mesmo tempo que é trabalhada, exaurida e recriada, transforma-se em relação social, adquire diversas formas sociais. Deixa de ser inocente, transforma-se em história. A partir da larga e intensa incorporação pelo capital, transformam-se também as condições de luta pela terra. As relações e as divergências das classes estendem-se da cidade ao campo e do campo à cidade. Da mesma maneira que se generaliza o predomínio do capital e da burguesia, generalizase a classe operária. Também o campesinato se transforma: proletarizando-se; seguindo adiante, em busca de outras terras; ou sendo recriado pelas exigências da produção mercantil. Alargam-se as contradições de classes, no âmbito dos movimentos sociais e partidos pol fiticos. As mesmas relaçóes de produção que realizam a subordinação do campo à cidade, da agricultura à indústria, da terra ao capital, realizam o desenvolvimento das classes sociais em escala nacional. Al começa outra história.

(33) Karl Marx: El Capital, 3 tomos, tradução de Wenceslao Roces, México, Fondo de Cultura Económica, 1946-47, tomo I, pp. 553-555; citaçao extraída do cap. XIII, intitulado "Maquinaria e Grande Indústria", item 10, sobre "A grande indústria e a agricultura". 